\title{
ペリオテストの測定再現性について
}

\author{
貞光謙一郎 ${ }^{1}$, 加藤泰二 ${ }^{2}$
}

\section{About the measurement reproducibility of Periotest}

\author{
Ken-ichirou Sadamitsu, Taiji Kato
}

In recent years, Implant treatment has been recognized to be a predictable treatment of defect prosthetic, defect prosthetic treatment using implants has become much more familiar to the general practice.

However, implant position and ossein, bone density, power of healing is not uniform through a period of integration, it becomes accident and not to integration with the patient's problems if moving to the prosthetic treatment by judging only clinical senses such as inspection, palpation, and percussion sound and standard healing.

Periotest have ways to prevent such accidents. Periotest is more convenient to confirm the primary stability and integration, which can be diagnosed more reliably measuring device.

The Periotest in the literature for some numbers are not stable and integration is broken by hammering there is a negative feedback, but it had the feeling like its not really try to use.

We report devices that can be used with confidence for diagnostic equipment integrations and should be noted for measurement by examining the reproducibility of the Periotest measurement.

近年，インプラント治療は予知性のある欠損補綴治療として認知されており，一般臨床 におけるインプラント欠損補緅治療はかなり身近なものとなっている.

しかしながら，インプラント埋入の部位や骨質，骨密度，患者自身の治癒力などによっ てインテグレーションの時期は一様ではなく，視診，触診，打診音などの臨床的な感覚や 標準的な免荷期間だけの判断で最終補緅に移った場合，実際にインテグレーションしてい なければアクシデントの原因となり，患者さんとのトラブルにもなりかねない.

このようなアクシデントを起こさないためにも，初期固定やインテグレーションの確認 をより簡便に，より確実に診断できる測定装置としてペリオテストがある.

しかしペリオテストに関しては，一部文献等において，数值が安定しない，桘打によっ てオッセオインテグレーションが壊されるなどという否定的な意見があるが，実際に使用

${ }^{1}$ 貞光歯科医院 Sadamitsu dental clinic

片いき歯科クリニック Daiki dental clinic 
してみてそのような感覚は受けない.

そこで，ペリオテストの測定再現性を調べることにより，オッセオインテグレーション の診断機器としてょり安心して使用できる装置であることが証明され, 測定に関して注意 すべき事項も見出せたので報告する。

Key word：インプラント Implant, インテグレーション Integration, ペリオテスト Periotest, テンポラリーセメント Temporary Cement, アバットメント Abutment

\section{緒言}

現在発売されているルートタイプのチタン製インプラン トは,インプラント各社が多種多様なシステムを送り出し, また改良も加えられているため, その良し悪しの判断は付 けようがない.

インプラントフィクスチャーの表面性状には, 生物学的 反応から機械研磨, ブラストエッチング, TPS, SLA な どの「Bioinert」とHA コーテッドなどの「Bioactive」に 分けられ, それぞれオッセオインテグレーション, バイオ インテグレーションとして骨と結合し, 適材適所としてイ ンプラントの選択ができるようになった。

インプラントフィクスチャーは咬合を与えることによっ て初めて機能するが, 埋入したインプラントに機能圧をか けるタイミングについてはさまざまな討議1, 2) が行われて いる. 初期のインテグレーションについては, ブローネマ ルクらによって提唱され, 確立された 2 回法インプラント 治療術式からも, 粘膜下での治癒期間が上顎では $4 \sim 6$ カ 月, 下顎では 3 カ月は絶対必要 ${ }^{3)}$ とされていた。しかし, ITIの登場により 1 回法でなんら問題がないばかりか, 上 顎においても3カ月で十分なオッセオインテグレーション が獲得できることも明らかになった。

また，HA コーテッドインプラントを用いた埋入後の速

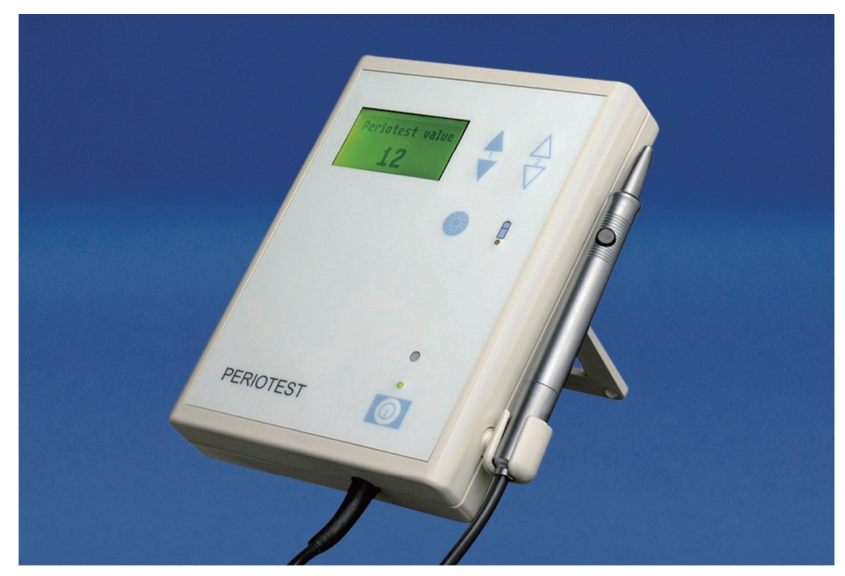

図 1 ペリオテスト (グルデン社, 輸入元 : 東京歯科産業)
やかでメカニカルな初期固定が得られたとしても，最低3 カ月の免荷期間を設けた方が無難であるとも考えられてい る $^{4)}$.

フィクスチャーの種類，埋入の時期，埋入部位や顎骨の 骨質, 骨密度, 患者自身の治癒力などによってインテグレ ーションの時期は一様ではなく, 免荷期間不足や荷重時期 の読み違い, 火傷やコンプレッション・ネクローシス, 感 染などのテクニカルエラー等によってもインテグレーショ ンは左右される ${ }^{5)}$.

そのため, 最終補綴に移る前に負荷をかける時期を視診, 触診，打診音などの臨床的な感覚や提唱されている免荷期 間を基準に考えれば良いというものではない.アクシデン トを起こさないためにも, 埋入したインプラントフィクス チャーにアバットメントを装着した段階で，上部構造の製 作，装着へと治療をすす好，あるいは治癒するまで待 つべきかの判断は必要不可欠なことであり,やむをえない.

そこで, 著者らは実際の臨床においてインプラントの初 期固定やインテグレーションの確認をより簡便に, より確 実に診断するための測定機，ペリオテスト（グルデン社， 輸入元：東京歯科産業) (図 1 ) を用いてインテグレーシ ヨンの程度を把握しているが，ペリオテストのインプラン トへの使用は, 数值が安定しない, 槌打によってオッセオ インテグレーションが壊されるなどの否定的な意見 ${ }^{6)}$ があ るが，実際の臨床ではそのように感じたことはなかったの で，今回ペリオテストを用いてのインプラントのインテグ レーションを測定し，その測定再現性を調べてみることに した.

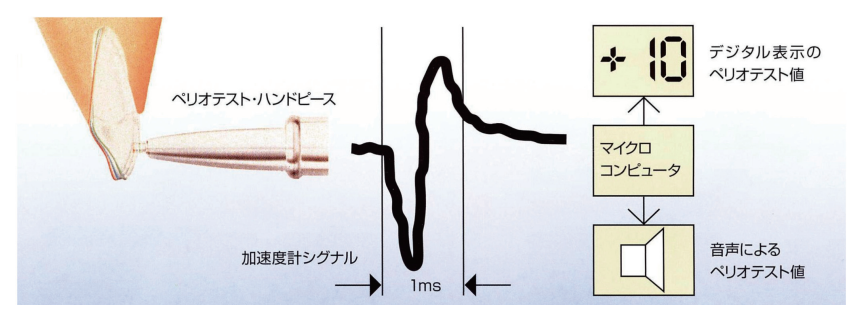

図2 ペリオテスト測定原理 


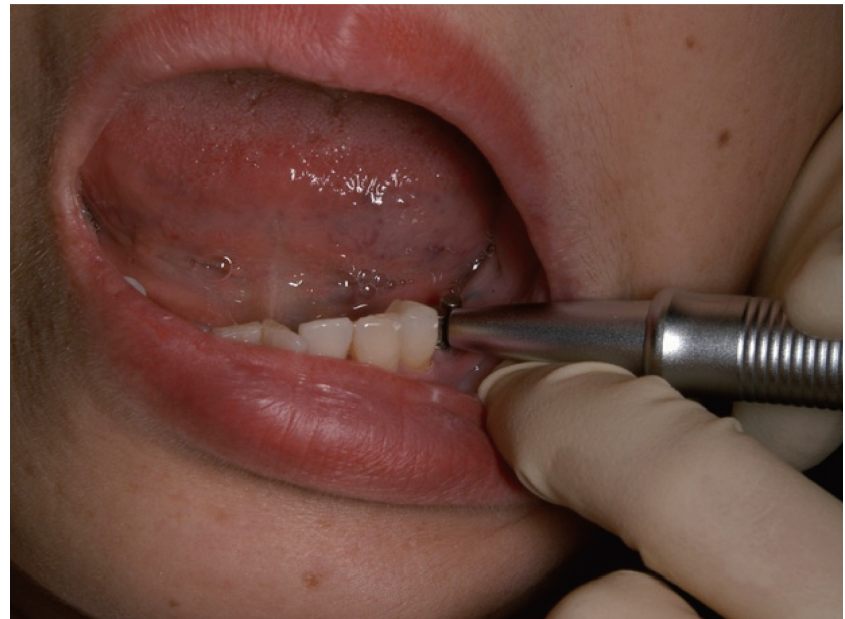

図3 ペリオテスト計測風景

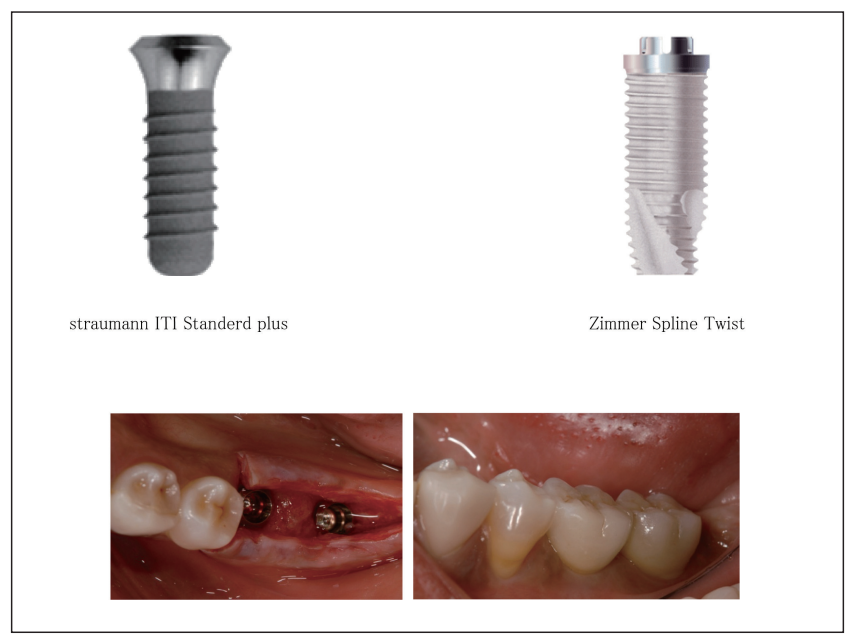

図5＼cjkstart計測対象インプラント

\section{研究の方法}

\section{I . 測定方法}

今回測定に用いたペリオテストは，電子駆動方式による ハンドピースのタッピングヘッドが1秒間に 4 回，4秒間 の計 16 回歯面を打診し，歯周組織が健全であれば歯の安 定度が大きく, 歯面を軽打したタッピングヘッドはより速 く戻り，歯槽骨や軟組織に異常があるとタッピングヘッド の接触時間が1ミリセカンドの何分の 1 か長くなり，この 微妙な接触時間の差異をマイクロコンピュータが正確に算 出して平均值を $-8 \sim+50$ の数值でペリオテスト值（以 下PT 值とする）として表示するものである（図２）.

実際の測定に関しては，ペリオテストのハンドピースの 先端がアバットメントおよび最終補緅物の長軸と直角で, 床と平行になるように固定し（図３），また臨床的かつ経 験的な根拠から得られたブローネマルクのプロトコールを 準用して，上顎では埋入 4 カ月後からの，下顎では埋入 3

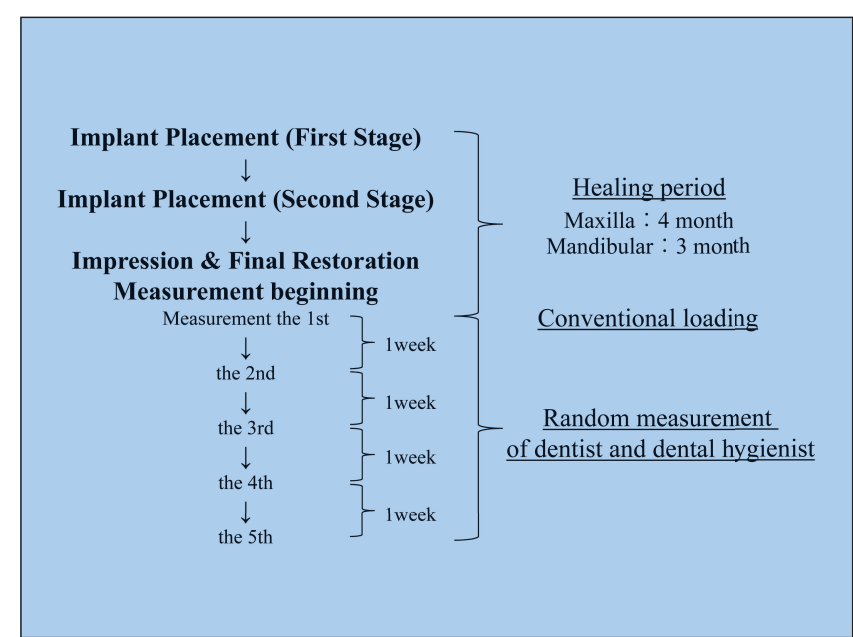

図4 計測プロトコール

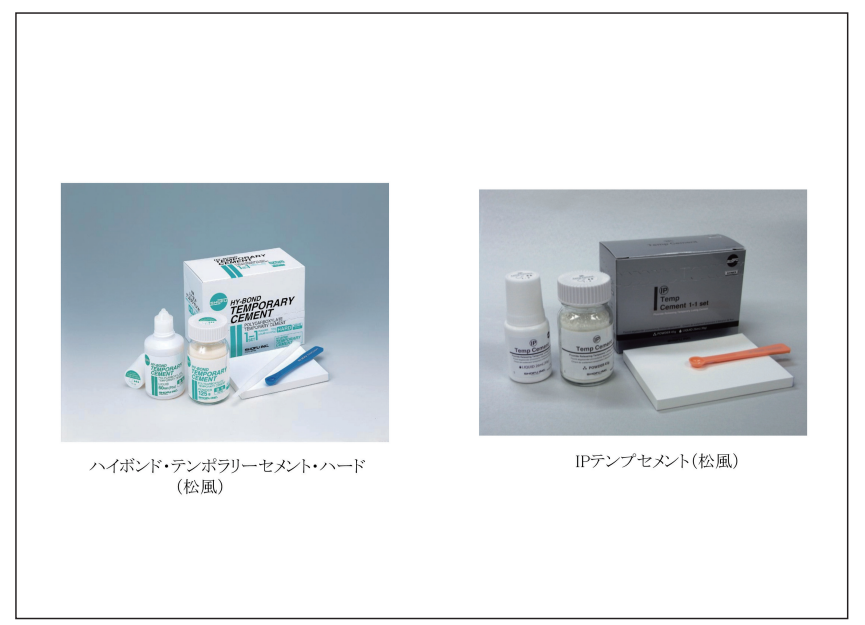

図6＼cjkstart計測対象テンポラリーセメント

カ月後からの 1 週間おきに計 5 回，歯科医師および歯科衛 生士がランダムに計測を行った（図４）。

\section{II. 測定対象}

測定対象となるインプラントフィクスチャーは，著者ら が日常臨床に用いているオッセオインテグレーションイン プラントである straumann 社のITI Standard Plus（以下 ITI とする）とバイオインテグレーションインプラントで ある Zimmer 社のSpline Twist（以下Spline とする）の2 種類を用いた（図５）。

測定を行ったインプラントフィクスチャーは実際患者に 埋入したもので，通常 Splineは，成熟側に比較して骨質 の劣る部位への埋入に用いるが，今回は測定条件を同じに するためにITI, Spline ともに成熟側への埋入とし，埋入 深度は歯肉縁下 $2 \sim 3 \mathrm{~mm}$ とした。

測定を行うにあたってフイクスチャー上に装着したアバ ットメントは, ITIにはソリッドアバットメントを, 
表 1-1アバットメント槌打の測定結果（straumann ITI）

\begin{tabular}{|c|c|c|c|c|c|}
\hline & 1 week & 2 week & 3 week & 4 week & 5 week \\
\hline$\sqrt{6}$ & -5 & -5 & -5 & -5 & -5 \\
\hline$\sqrt{6}$ & -5 & -5 & -5 & -5 & -5 \\
\hline$\sqrt{6}$ & -5 & -5 & -5 & -5 & -5 \\
\hline$\sqrt{6}$ & -5 & -5 & -5 & -5 & -5 \\
\hline 6 & -6 & -6 & -6 & -6 & -6 \\
\hline 6 & -5 & -5 & -5 & -5 & -5 \\
\hline 6 & -6 & -6 & -6 & -6 & -6 \\
\hline
\end{tabular}

Spline にはカスタムアバットメントをおのおののメーカー の指示する締め付けトルク值, $35 \mathrm{Ncm}$ および $30 \mathrm{Ncm} に て$ 装着し，最終修復物には陶材焼付鋳造冠を用いた。

フィクスチャーに接合したアバットメント上に最終修復 物を装着する方法には，スクリューによる固定とセメント による固定がある，スクリュー固定は天然歯に近似すべく 審美性や望むべく部位での咬合接触を得ることができず， また歯冠中央部付近のアクセスホールの存在による陶材な どの歯冠修復物の強度の低下を招く恐れがある。さらに, アバットメントスクリューの緩み等の問題が生じる可能性 が高い7,8) ため, 最終修復物の撤去によってそれに対処で きるよう，著者はテンポラリーセメントを用いて最終修復 物の固定を行っている.

そこで今回は, 松風社のハイボンド・テンポラリーセメ ント・ハード（以下ハードとする）と同社のIPテンプセ メント（以下IPテンプとする）の 2 種類を用いることに した(図6).

\section{III. インプラントフィクスチャーについての評価}

ITI と Spline は材質や表面性状の違いや，インターナル

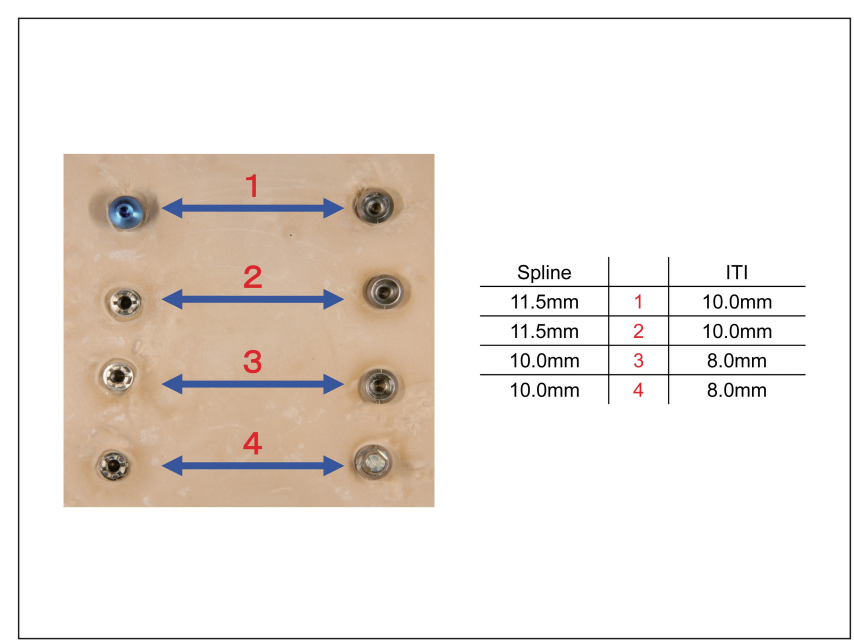

図7 テストピース

表 1-2アアバットメント棺打の測定結果 (Zimmer Spline Twist)

\begin{tabular}{|c|c|c|c|c|c|}
\hline & 1 week & 2 week & 3 week & 4 week & 5 week \\
\hline 5 & -4 & -4 & -4 & -4 & -4 \\
\hline$\lcm{6}$ & -4 & -4 & -4 & -4 & -4 \\
\hline 6] & 01 & 01 & 00 & 00 & 01 \\
\hline$\sqrt{2}$ & -1 & -1 & -1 & -2 & -2 \\
\hline 61 & -1 & -1 & -1 & -1 & -2 \\
\hline
\end{tabular}

ヘックスであるITI，エクスターナルヘックスである Spline というようにアバットメントとの結合様式の違いが あるために，これらがPT 值の違いとして現れる可能性が あると考えた。

そこで，骨密度やインテグレーションの影響を受けない 状態を作るために，ITI およびSplineのおのおののフィク スチャーを石膏に埋没しテストピースを作製した。テスト ピース上のフィクスチャーに3 名の術者がそれぞれアバッ トメントをメーカー指定のトルク值（ITI は $35 \mathrm{Ncm}$, Spline は30Ncm）にて装着し,PT 值を見ることにした（図 7).

なお，使用したフィクスチャーはITI では $4.1 \mathrm{~mm}$ 径の $8.0 \mathrm{~m} \mathrm{~m}$ と $10.0 \mathrm{~m} \mathrm{~m}$, Spline では $3.75 \mathrm{~m} \mathrm{~m}$ 径の $10.0 \mathrm{~m} \mathrm{~m}$ と $11.5 \mathrm{~mm}$ の各 2 本ずつとした.

\section{結果}

\section{I ． 測定再現性の評価（表1-1，1-2）}

アバットメントを直接桘打したペリオテストの結果, ITI では装着 1 週間後からのPT 值はすべてにおいて -5 
表2-1 アバットメントと最終補緅物槌打の測定結果（straumann ITI)

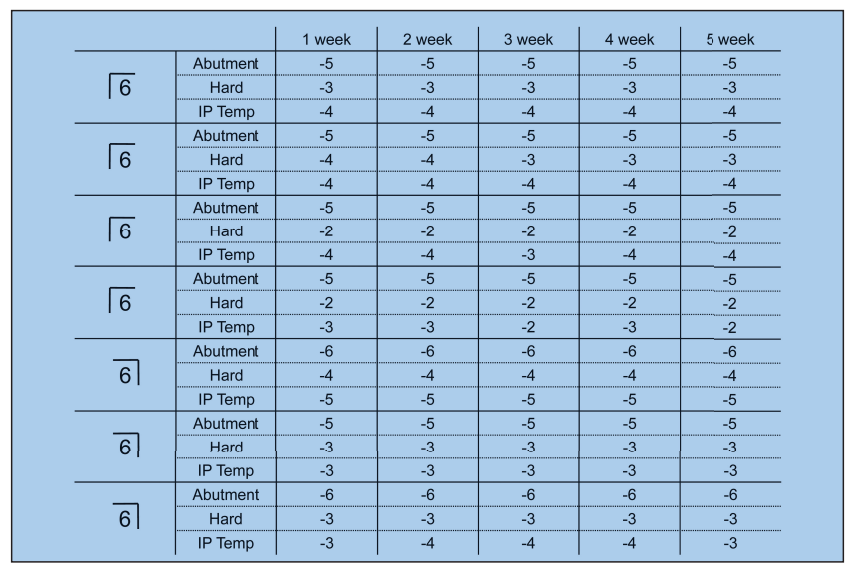

からー6を示し比較的安定した結果が得られた。

それに対してSplineでは, 01からー4を示し, ITIに比 較してPT 值の幅が認められたが，ITI， Spline ともにお のおのの計測間ごとの PT 值には有意な差は認められず, また計測者間においても差が認められなかった。

しかし，ITI とSplineのPT 值の間には有意な差が認め られた。

\section{II . 仮着セメントによる評価（表 2-1，2-2）}

アバットメントに 2 種類のテンポラリーセメントをおの おの介して装着した最終修復物を桘打したペリオテストの 結果，ITI ではハード，IPテンプともにアバットメントを 直接桘打するよりも，すべてにおいてー3からー1の範囲 で上昇し，高い数值が示された。

これに対してSplineにおいても同様に，セメントを介 した方の数值が高く現れたが，ITI， Spline ともに 2 種類 のテンポラリーセメント間およびアバットメントとIPテ ンプ間にはPT 值において有意な差は認められず，アバッ トメントとハード間には有意な差が認められた。

\section{III. インプラントフィクスチャーの評価（表 3$)$}

アバットメントを直接槌打したペリオテストの結果で, ITIにおいてはどれも-5より低いPT 值を示したのに対 してSplineでは01からー4の幅でのPT 值を示し，ITIに 比較し安定度が低いことがうかがわれた。

これに関しては実際の臨床実感においても同様で，ITI より Spline の数值が高く現れる感じを受けるが，ITIに比 較して Spline の方がインテグレーションしていないとも 考えられない。

そこで，インテグレーションや骨質の影響を除くために 各フィクスチャーを石亳に埋没したテストピース上で桘打 したペリオテストの結果，各測定者とも ITI ではー4から
表2-2 アバットメントと最終補綴物槌打の測定結果（Zimmer Spline Twist)

\begin{tabular}{|c|c|c|c|c|c|c|}
\hline & & 1 week & 2 week & 3 week & 4 week & 5 week \\
\hline \multirow{3}{*}{5} & Abutment & -4 & -4 & -4 & -4 & -4 \\
\hline & Hard & 01 & 01 & 01 & 01 & 01 \\
\hline & IP Temp & 0 & 0 & 0 & 0 & 0 \\
\hline \multirow{3}{*}{6} & Abutment & -4 & -4 & -4 & -4 & -4 \\
\hline & Hard & -1 & -1 & 0 & -1 & -1 \\
\hline & IP Temp & -1 & -1 & -1 & -2 & -2 \\
\hline \multirow{3}{*}{6} & Abutment & 01 & 01 & 00 & 00 & 01 \\
\hline & Hard & 06 & 08 & 08 & 07 & 06 \\
\hline & IP Temp & 05 & 06 & 06 & 06 & 06 \\
\hline \multirow{3}{*}{$\sqrt{2}$} & Abutment & -1 & -1 & -1 & -2 & -2 \\
\hline & Hard & 04 & 04 & 04 & 03 & 04 \\
\hline & IP Temp & 05 & 05 & 06 & 05 & 05 \\
\hline \multirow{3}{*}{6} & Abutment & -1 & -1 & -1 & -1 & -2 \\
\hline & Hard & 02 & 02 & 01 & 01 & 01 \\
\hline & IP Temp & 01 & 01 & 02 & 02 & 02 \\
\hline
\end{tabular}

表3 テストピースアバットメント槌打の測定結果

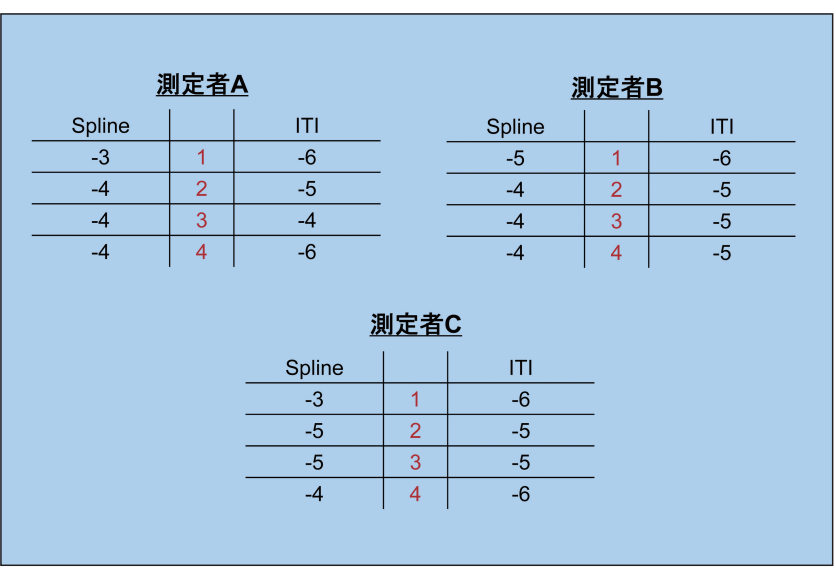

-6の範囲を示し, Spline ではー3からー5の範囲を示した。 測定者間でのばらつきは認められなかったが, ITIに比 べSpline のPT 值の方が高い值を示し，有意な差が認めら れたことからも, SplineのPT 值が高く示されるのは骨密 度やインテグレーションの状態によるものではないことか らもインテグレーションや骨質による差は認められないと 考えられる。

\section{考察}

\section{I ．測定再現性の評価}

インプラントのインテグレーションの程度を計測する機 器にはペリオテスト以外にも RFA（Resonance Frequency Analysis）による計測も注目されているが，非接触式であ るがゆえ計測に際してインプラント別の測定用アタッチメ ント（トランデューサー）を装着する必要があり，計測の たびにアバットメントやアタッチメントを外さなければな らず臨床的利便性に欠け，数值に関しても否定的な意見 ${ }^{9)}$ がある。

しかし，これに対してペリオテストにおいても数值が安 


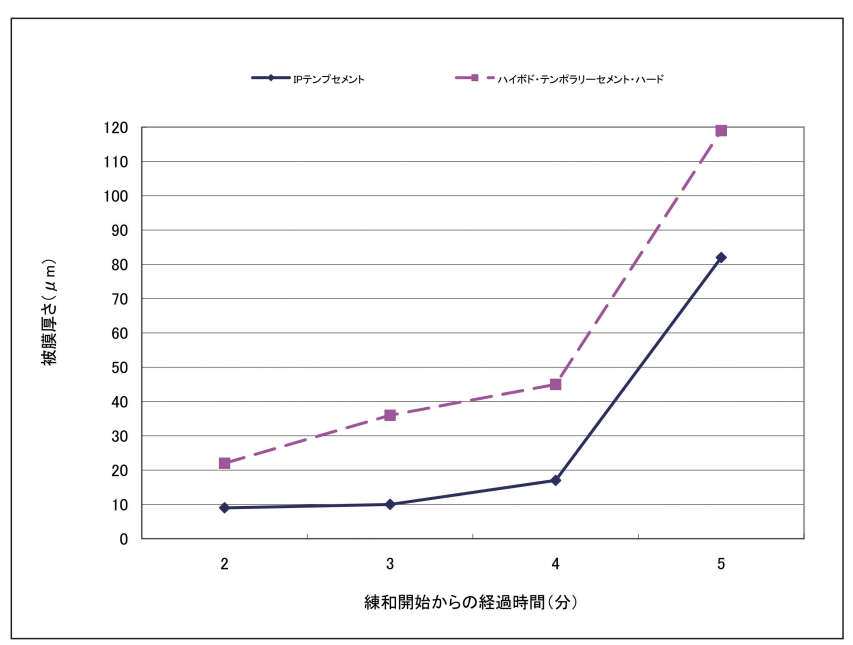

図8 セメント被膜厚さの経時的変化（松風社データ）

定しない，桘打によってオッセオインテグレーションが壊

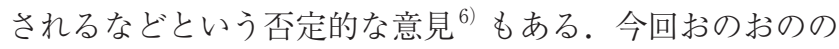
アバットメントを直接槌打した測定間ごとの PT 值には優 位な差が認められなかったことからも，「ペリオテストの 数值が安定しない」,「桘打によってオッセオインテグレー ションが壊される」などという否定的な意見は覆され，同 時に測定再現性も高いと言える。

また，ペリオテストを用いたインテグレーションの研究 では, ITI どのバイオネイトインプラントを用いた研究 結果に扔いても, Spline などのバイオアクティブインプラ ントを用いた研究結果に抒いても, PT 值が6以上の場合 はインテグレーションしていないと報告10 12) されている. 今回の測定結果をみると, 良好なITI, Spline ともに良好 なインテグレーションが得られていると考えられる.

\section{II. 仮着セメントによる評価}

アバットメントと最終補綴物をつなぎ止めるセメントの 種類によっても材質の違い, 硬化時間の違い, 硬化硬度の 違い, 皮膜厚さの違いによってPT 值は変化すると考えら れる。

実際の臨床に扔いて，定期検査などでペリオテストを用 いてインテグレーションを確認するにあたり，計測のたび に最終補綴物を除去し，アバットメントを露出させた状態 で桘打するのも現実問題難しいのではないだろうか.

やはり，最終修復物上を桘打して測定する方が患者への 負担, 最終修復物の破損等を防ぐことができると考えられ る.

そのため, インプラントフィクスチャーの動摇度を確認 するためにはアバットメントを直接槌打する感覚に近いセ メントの方がペリオテストの測定再現性から考えるとよい であろうと考えられる。

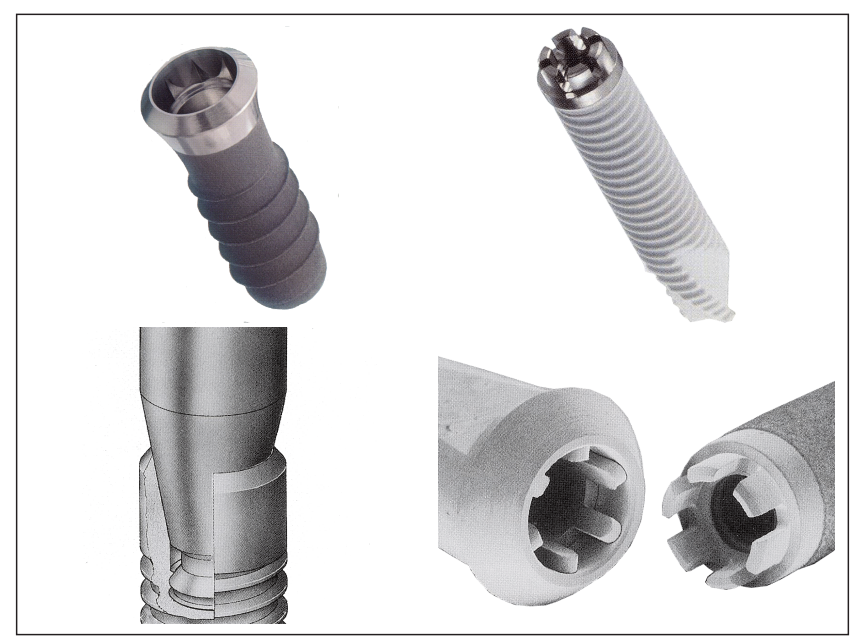

図9 結合様式の違い

そこで, IP テンプよりハードの方が高い数值を示した が，これはテンポラリーセメントを介した最終補綴物を桘 打した方のPT 值が高くなるのは，セメント材の介在によ ってその厚みが錧打の振動を吸収するのではないかと考え られる。

よってハードに比較してIP テンプの方がセメント皮膜 厚さが小さいことから（図８） PT 值の上昇を少なくし, 棺打の振動が吸収されることなくアバットメントを直接桘 打した感覚に近いのではないかと考えられる.

また，セメント皮膜厚さが小さいと最終修復物の浮き上 がりの心配もなく，良好な咬合接触関係が得られる。

\section{III. インプラントフィクスチャーの評価}

ITI については下顎骨への埋入, Spline については上顎 骨への埋入と使い分けることが多いため，天然歯に打いて も上顎歯は下顎歯よりも高いPT 值を示すことから, さら に成熟側への埋入と抜歯即時埋入ということからも考える と, 測定値に差や幅があるのは骨密度やインテグレーショ ンの方式の違いによるものだろうか.

しかし, 骨密度と PT 值には相関性がないとの報告 ${ }^{13)}$ があることからも，インテグレーションの状態に問題があ るのだろうか。

しかし, 実際の臨床での感覚として Spline のインテグ レーションが悪いように感じたこともなく，HA コーテッ ドインプラントのため初期固定を比較的早期に獲得でき, また骨誘導能があるにもかかわらず，ITIに比較して低い PT 值が示されるのには疑問が残る。

しかし, ITI と Spline は共に純チタン製のフィクスチャ 一ではあるが，インターナルヘックスとエクスターナルヘ ックスといったアバットメントの接合様式に大きな違いが あり（図 9), この接合様式の違いが PT 值の差や幅とし 
て表れ, 接合部構造やそれに対するおのおののアバットメ ントの構造の違いなどが，PT 值になんらかの影響を与え る可能性があると考えられる。

これに関して,アバットメントにかかる「ねじれトルク」 や「側方力」に対して, ITI と Spline は共に他のインプラ ントシステムに比較して強度が高いが，ITI と Spline 両者 を比べると Spline の方が強度が高いという数值が報告さ れている14).

強度が高いということを考えると，フィクスチャーとア バットメントの接合部に「ネバリ」があるととらえてもよ い.このことから, ITIより Splineの方がPT 值が高く出 るのも,「ネバリ」の差がPT值の差としてでてきている と考えられる。

\section{結論}

今回,ペリオテストに測定安定性があることが確認でき， 繰り返しの桘打によっても PT 值の上昇は認められなかっ た.このことからも, ペリオテストによるインテグレーシ ヨン破壊の可能性はないと考えられ, 臨床的に動摇が認め られない症例でも, 安定值を超えたPT 值の場合は, 急激 な負荷がかかったときに失敗例につながる高いリスクを伴 うと考えられるので, 免荷期間後および最終修復前にはぜ ひ検査したい項目である。

\section{参考文献}

1) Aparicio C, Rangert B, Sennerby L: Immediate/early loading of dental implants. A report from the Sociedad Espanole de Implantes World Congress consensus meeting in Barcelona, Spain 2002. Implant Dent Relat Res 5:57-60, 2003.

2) Cochran D L, Moeton D, Weber H P: Consensus statements and recommended clinical procedures regarding loading protocols for endosseous dental implants. Int j Oral Maxillofac Implants 19 (suppl) :109-113, 2004.

3) Brånemark P-I, Hansson B O, Adell R, Breine U, Lindström J, Hallén O, Ohman A: Osseointegrated implants in the treatment of the edentulous jaw. Experience from a 10-year period. Scand J Plast Reconstr Surg Suppl 16:1-132, 1977.

4) Botticelli D, Berglundh T, Lindhe J: Hard-tissue alterations following immediate implant placement in extraction sites. J Clin Periodont 31 (10):820-828, 2004.

5) 森田耕造 : トラブルから学ぶインプラント治療の注意点と リカバリー . J Oral Imp 19:7-37, 2004.

6) 藤澤健司, 宮本洋二, 桃田幸弘, 日比弓紀子, 長山 勝: イ ンプラントの安定性評価における共鳴振動周波数分析装置 と歯牙動摇度測定装置の比較.日口腔インプラント誌 18:406-414, 2005.

7) Preiskel HW, Tsolka P: Cement- and screw-retained implantsupported prostheses. up to 10 years of follow-up of a new design. Int J Oral Maxillofac Imp 19 (1) :87-91, 2004.
もし安定值が得られなかった場合は，免荷期間をもう少 し延ばし経過を観察していきたい。それでも安定值が得ら れない場合は再埋入を考えるべきである。

また，セメンティングにてアバットメント上に最終修復 物を装着する際には，PT值や咬合に影響を与えない，被 膜厚さが薄く，圧縮強度の高いセメントを用いる必要があ る.

さらに，インターナルヘックス，アウターナルヘックス というインプラントフィクスチャーとアバットメントの接 合部の構造や，アバットメントの形状の違いによって数值 は変わってくるので，ペリオテストの PT 值とインテグレ ーションの程度を一律に数值化するのは難しいと思われ る。したがって，実際に使用するインプラントシステムの 各種構造やそれに対する $\mathrm{PT}$ 值を知っておく必要がある.

\section{おわりに}

インプラント治療にあたっては，診査診断，治療計画を しっかりと立て，ペリオテストを用いることにより最終修 復後のトラブルを未然に防ぐことができると思われる.

アクシデントなく治療を終えることは, 患者さんとの信 頼関係をより深いものにできると考えられるので，オッセ オインテグレーションの確認にはぜひ，ペリオテストを使 用したいものである。

8) Michalakis KX, Hirayama H, Garefis PD: Cement-retained versus screw-retained implant restorations: a critical review. Int J Oral Maxillofac Imp 18 (5) :719-28, 2003.

9) Katsunori K, Yasumasa A: Review for immediate loading implant. Immediate loading implants. Practice in Prosthodontics (Extra Issue) :14-18, 2006.

10) Schulte W, Lukas D: Periotest to monitor osseointegration and to Check the occlusion in oral implantology. J Oral Imp XIX (1) : 23-32, 1993.

11) Rotter BE, Blackwell R, Dalton G: Testing progressive loading of endosteal implant with the periotest. A pilot study. Implant Dentistry 5 (1) : 28-32, 1996.

12) Cannizzaro G, Leone M: Restoration of partially edentulous patients using dental implants with a microtextured surface: a prospective comparison of delayed and immediate full occlusal loading. Int J Oral Maxillofac Imp 18 (4) :512-522, 2003.

13) Mericske-Stern R, Milani D, Mericske E, et al: Periotest measurements and osseointegration of mandibular ITI implants supportiong overdentures. Clin Oral Imp Res 6:73-82, 1995.

14) Osamu T, Takeo M, Paul P Binon: New Currents of the Implant/Abutment Connections. Increasing Resistance to Screw Loosening and the Fracture. Quint Dent IMP 4 (4) : 54-61, 1997. 